Article

\title{
Enzybiotics LYSSTAPH-S and LYSDERM-S as Potential Therapeutic Agents for Chronic MRSA Wound Infections
}

\author{
Lukáš Vacek ${ }^{1,2}{ }^{1}$, Šárka Kobzová ${ }^{1}$, Richard Čmelík ${ }^{3}$, Roman Pantůček ${ }^{4}(\mathbb{D}$ and \\ Lubomír Janda $1, *$ (D) \\ 1 Clinical Immunology and Immunology of Infectious Diseases, Veterinary Research Institute, Brno, \\ Hudcova 70, 62100 Brno, Czech Republic; vacek@vri.cz (L.V.); kobzova@vri.cz (Š.K.) \\ 2 Department of Microbiology, St. Anne's University Hospital Brno and Faculty of Medicine, \\ Masaryk University, Brno, Pekařská 53, 65691 Brno, Czech Republic \\ 3 Institute of Analytical Chemistry of the Czech Academy of Sciences, Veveři 97, 60200 Brno, Czech Republic; \\ cmelik@iach.cz \\ 4 Department of Experimental Biology, Faculty of Science, Masaryk University, Kamenice 5, 62500 Brno, \\ Czech Republic; pantucek@sci.muni.cz \\ * Correspondence: janda@vri.cz; Tel.: +420-533-331-344
}

Received: 30 June 2020; Accepted: 12 August 2020; Published: 15 August 2020

check for updates

\begin{abstract}
Antibacterial antibiotic therapy has played an important role in the treatment of bacterial infections for almost a century. The increasing resistance of pathogenic bacteria to antibiotics leads to an attempt to use previously neglected antibacterial therapies. Here we provide information on the two recombinantly modified antistaphylococcal enzymes derived from lysostaphin (LYSSTAPH-S) and endolysin (LYSDERM-S) derived from kayvirus 812F1 whose target sites reside in the bacterial cell wall. LYSSTAPH-S showed a stable antimicrobial effect over 24-h testing, even in concentrations lower than $1 \mu \mathrm{g} / \mathrm{mL}$ across a wide variety of epidemiologically important sequence types (STs) of methicillin-resistant Staphylococcus aureus (MRSA), especially in the stationary phase of growth (status comparable to chronic infections). LYSDERM-S showed a less potent antimicrobial effect that lasted only a few hours at concentrations of $15 \mu \mathrm{g} / \mathrm{mL}$ and higher. Our data indicate that these antimicrobial enzymes could be of substantial help in the treatment of chronic MRSA wound infections.
\end{abstract}

Keywords: enzyme therapy; enzybiotics; lysostaphin; LYSSTAPH-S; endolysin; LYSDERM-S; MRSA

\section{Introduction}

Antibiotic resistance poses an increased threat for patients' health, prolongs stays in hospitals, and consumes more healthcare resources. In response to this threat, the WHO in 2015 announced the Global action plan on antimicrobial resistance, which sets out strategic objectives to reduce antimicrobial resistance impacts. According to this effort, research and development are needed to produce a novel approach to treatments that could be deployed against antibiotic-resistant infections [1-6].

Following this endeavor, this article focuses on promising antimicrobial enzymes LYSSTAPH-S (lysostaphin derivative) and LYSDERM-S (kayvirus 812F1 endolysin derivative) and their antibacterial potential against epidemiologically important sequence types (ST) of methicillin-resistant Staphylococcus aureus commonly found in chronic infections.

Not surprisingly, the bacterial cell wall is the target of antibacterial therapies. The cell wall of $S$. aureus is primarily composed of peptidoglycan, teichoic acids, and various surface proteins. Peptidoglycan itself consists of glycan chains of alternating $\beta-(1,4)$-linked N-acetylglucosamine (NAG) and N-acetylmuramic acid (NAM; a variant of NAG with a D-lactate attached to the C-3 by an ether 
bond). Stem pentapeptides (L-Ala-D-iso-Gln-L-Lys-D-Ala-D-Ala) are covalently linked to the carboxyl carbon of the D-lactyl group of NAM, and interpeptide bridges (pentaglycines, i.e., chain of five glycine residues) connect the L-Lys component of one stem peptide to the D-Ala of a neighboring stem peptide, Figure 1. In this manner, glycan strands are cross-linked by stem peptides and pentaglycines and form a complex net of peptidoglycan (murein) sacculus [7].

\section{Staphylococcus aureus peptidoglycan architecture and target sites of lytic enzymes}

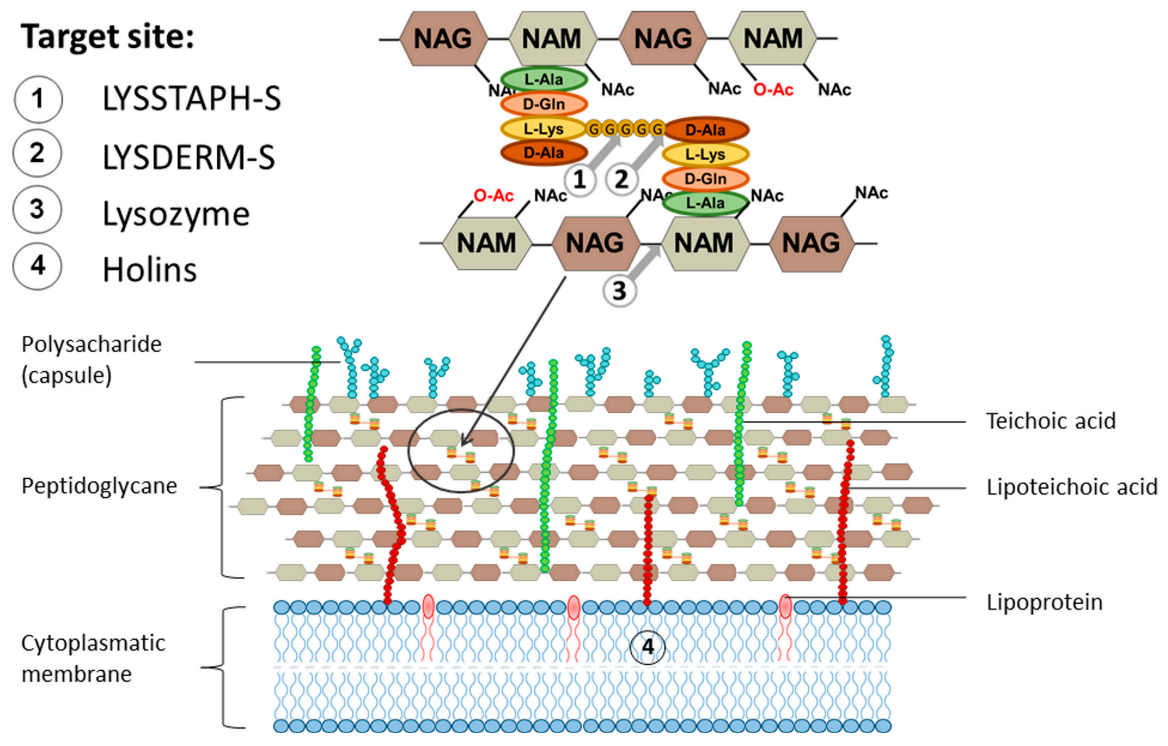

Figure 1. The cell wall of Staphylococcus aureus with the detailed structure of peptidoglycan. Cleavage sites of endolysin, lysostaphin, and lysozyme and target site of holins are marked 1 to 4 respectively.

Further, the antimicrobial enzymes lysostaphin and endolysin LysK, from which LYSSTAPH-S and LYDERM-S were derived, will be described.

\subsection{Lysostaphin}

Lysostaphin (EC 3.4.24.75), a glycyl-glycine endopeptidase, is a bacteriocin secreted by the Gram-positive bacterium Staphylococcus simulans. Bacteriocins, in general, are antibacterial proteins (and peptides) produced by bacteria as a competitive advantage over closely related species and cause growth inhibition or kill other bacterial species. Lysostaphin possesses bacteriolytic activity against staphylococci with pentaglycine interpeptide bridges because it specifically cleaves the bond between two glycines in the interpeptide bridge. As mentioned above, this is a distinct feature of the S. aureus cell wall and, thus, target selectivity is provided. Though its discovery and antimicrobial activity against S. aureus has been reported as early as the 1960s by Schindler and Schuhardt, its X-ray crystal structure has been reported only recently. Mature lysostaphin consists of an N-terminal catalytic domain with $\mathrm{Zn}^{2+}$-coordinating amino acid residues and a C-terminal cell wall targeting domain $[8,9]$.

As shown earlier, every clinical application of the antimicrobial drug so far involved the development of antimicrobial resistance. Mechanisms associated with lysostaphin resistance usually involve mutations in fem genes. Fem factors catalyze the non-ribosomal synthesis of pentaglycine cross-bridges, which are essential for the addition of glycine residues 2 and 3 (FemA) and 4 and 5 (FemB). Mutations affecting femA renders this gene non-functional, resulting in the formation of monoglycine cross-bridges instead of pentaglycine ones, thus conveying partial or complete resistance to lysostaphin. Resistance can also be achieved by the incorporation of serines in place of some glycines in the cross-bridge [10-12]. 
Morikawa et al. [13] also identified the $\operatorname{sig} B$ gene as a regulator influencing the cell wall thickness. Cells depleted in $\operatorname{sig} B$ developed thinner envelopes and demonstrated increased sensitivity to lysostaphin. Conversely, overexpression of $\operatorname{sig} B$ led to increased resistance to lysostaphin [13]. In addition, Koehl et al. [14] connected an increased lysostaphin resistance of $S$. aureus to the thickened cell wall found in vancomycin intermediate-resistant S. aureus (VISA) strains, and also to a decreased autolytic activity. Gründling et al. [15] later identified another gene, lyrA, that caused a high degree of lysostaphin resistance $[13,14]$.

Even though there are several reports of resistance development in S. aureus to lysostaphin, it seems that every resistance mechanism has its significant drawbacks. Kusuma et al. [11] demonstrated that mutations in fem $A$ led to reduced growth rate and virulence in a mouse kidney infection model in comparison to their wild-type parental strains. Moreover, other work showed a clear relationship between fem $A$-mediated lysostaphin resistance and increased susceptibility to $\beta$-lactams. It has been shown that the modified transpeptidase-penicillin-binding protein 2a (PBP 2a) encoded by the mec $A$ gene, which is responsible for $\beta$-lactam resistance in MRSA strains, cannot perform its function when only monoglycine cross-bridges are present. However, the regular PBP 2 transpeptidase is still capable of crosslinking stem peptides by monoglycine bridges. However, as a result of the situation, conventional beta-lactam antibiotics may inhibit PBP 2 , so that the resulting strains are again susceptible to methicillin [16-18].

\subsection{Endolysin LysK}

The LysK endopeptidase is one of the characterized endolysins derived from phage $\mathrm{K}$, a large broad-spectrum staphylococcal myovirus from the genus Kayvirus, recently reclassified to family of Herelleviridae. It consists of three domains typical for staphylococcal phage endolysins, the Cysteine, Histidine-dependent Amidohydrolase/Peptidase (CHAP) domain, the Amidase-2 domain (Ami-2), and the Src homology 3 - prokaryotic homologue (SH3b) domain. The cleavage site of the CHAP domain (D-Ala-Gly) and amidase domain (MurNAc-L-Ala) were revealed by mass spectrometry (MS) and the analysis of peptidoglycan digestion products. The SH3b cell wall binding domain is known to bind to the pentaglycine bridge, and similar activity was shown for the SH3b-like cell wall targeting domain of the lysostaphin. Further, the deletion construct consisting of the CHAP and SH3b domains, without the amidase domain was demonstrated to possess similar antibacterial activity as the full-length enzyme $[19,20]$.

LysK (in some articles, also referred to as GH15, Sb-1, G1, SA11, A5W, or 812) is one of the most potent staphylococcal phage endolysins with a broad-spectrum antibacterial activity. It has the capability to kill various strains of S. aureus, including MRSA and VRSA strains, as well as coagulase-negative staphylococci. Interestingly, the CHAP domain was also shown to have an even broader lytic spectrum than original LysK, with the activity towards bacteria of genera Streptococcus, Micrococcus, Arthrobacter, and others [19,21].

In has been hypothesized that during the co-evolution of phages and their bacterial hosts, endolysins have developed their activity toward conserved cell wall structures essential for survival, which makes the antibacterial resistance a rare event. As described earlier, the majority of resistance mechanisms are focused within the cell, and the extracellular application of endolysins hampers the possibility to develop resistance. Indeed, to our knowledge, bacterial resistance to endolysins has not yet been described. Nevertheless, researchers recently attempted to further reduce the possibility of resistance development by using fusion enzymes consisting of catalytic domains of LysK and lysostaphin [22-24]. 


\section{Results}

\subsection{Enzyme Preparation}

In this work, we used a new recombinant variant of lysostaphin - LYSSTAPH-S, which is characterized by a gene sequence optimized for heterologous expression in E. coli. The original amino acid sequence (WP_013012297.1) was truncated by 209 amino acids (predomain). The less hydrophobic methionine 237 was replaced by isoleucine [25]. The resulting recombinant DNA construct contained a ubiquitin gene, a $14 \times$ histidine anchor, a catalytic domain gene, and a cell wall binding domain gene. The entire fusion protein contains 356 amino acids with a total molecular weight of $39.163 \mathrm{kDa}$.

Further, we used a novel recombinant variant of lysostaphin LYSDERM-S optimized for heterologous expression in E. coli. The amino acid sequence for endolysin is based on the LysF1 construct [26]. The final construct contains a ubiquitin gene, a $14 \times$ histidine anchor, a CHAP domain, and a cell wall binding gene (SH3b domain). The entire fusion protein contains 395 amino acids with a total molecular weight of $43.653 \mathrm{kDa}$.

The protein production was comparable to other expression systems and achieved yields of $200 \mathrm{mg} / \mathrm{L}$ in both tested enzymes. The SDS-PAGE electrophoresis results of recombinant proteins LYSDERM-S and LYSSTAPH-S are depicted in Supplementary Material Figure S1.

\subsection{Plate Lysis Assay}

The antibacterial effect on selected $S$. aureus strains was evaluated semiquantitatively, as depicted in Figure 2. Clear zones were assessed as " +++ ", zones with minimal bacterial growth as " $++"$, zones with substantial bacterial growth as "+", and no visible zone as "-". The results were transformed into graphs for a simple comparison between strains and times of storage. Figure 2 shows results for S. aureus sequence types ST22 and ST30 at three different time points, freshly prepared, after six weeks of storage at $4{ }^{\circ} \mathrm{C}$, and after 12 weeks of enzyme solution storage at $4{ }^{\circ} \mathrm{C}$. The full results of the other tested S. aureus strains are shown in Supplementary Material Figures S2 and S3.

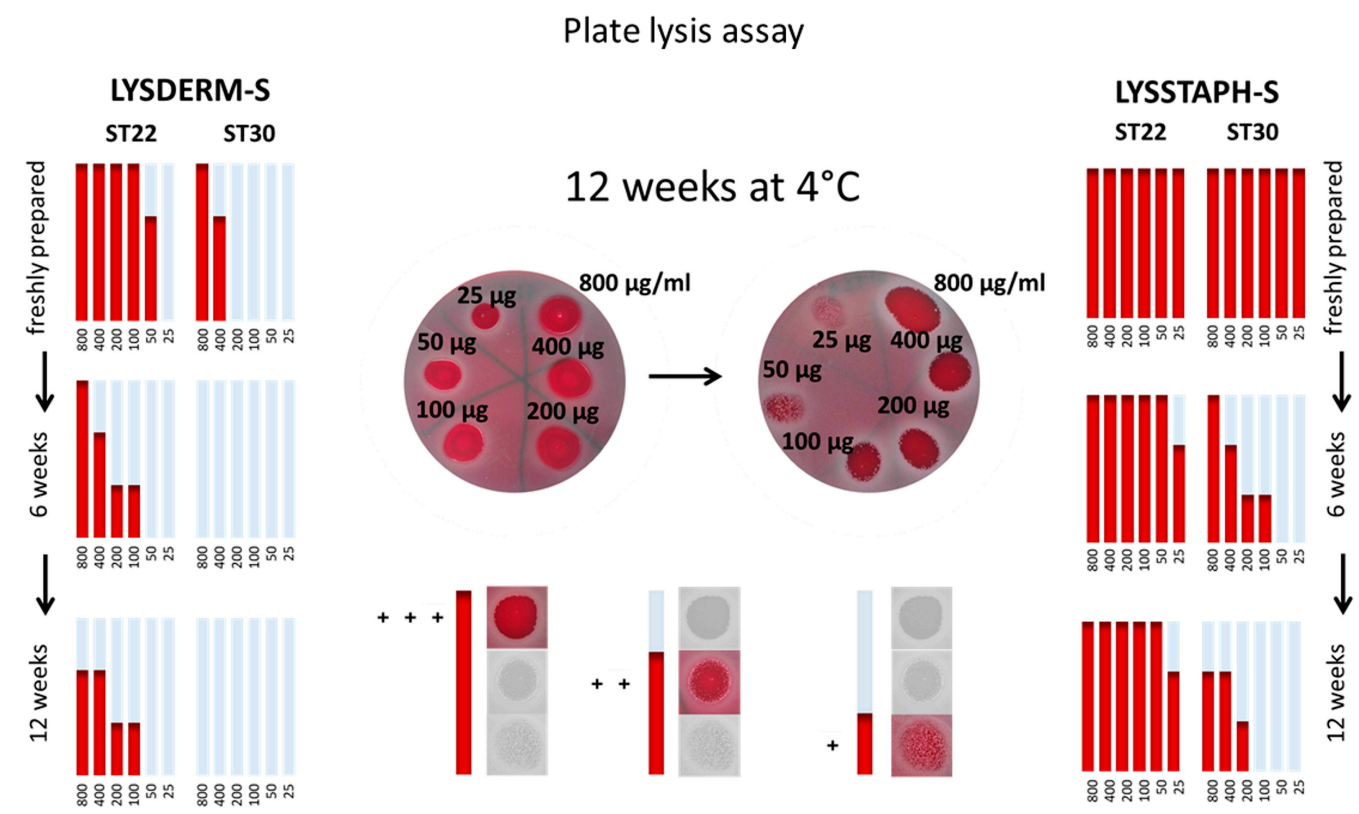

Figure 2. Antibacterial susceptibility of Staphylococcus aureus sequence types (ST) ST22 and ST30, at three different time points, freshly prepared, after six weeks of storage at $4{ }^{\circ} \mathrm{C}$, and after 12 weeks of storage at $4{ }^{\circ} \mathrm{C}$. LYSSTAPH-S and LYSDERM-S concentrations used: 800, 400, 200, 100, 50, $25 \mu \mathrm{g} / \mathrm{mL}$. Clear zones were assessed as " +++ ", zones with minimal bacterial growth as " ++ ", zones with substantial bacterial growth as "+", and no visible zone as "-". 
The results show a decrease in antibacterial susceptibility with prolonged time of storage, during which slow enzyme denaturation takes place. When the highest concentration of LYSSTAPH-S was used, the tested strains showed slightly reduced antimicrobial activity after 12 weeks $(93.6 \%)$ of storage at $4{ }^{\circ} \mathrm{C}$ compared to freshly prepared solutions (100\%) and after six weeks (100\%). In contrast, LYSDERM-S showed a decrease in antibacterial susceptibility of the tested strains after six weeks $(33.3 \%)$ compared to the freshly prepared enzyme (100\%). After 12 weeks of storage, no strain was susceptible to the enzyme. Thus, the degradation of LYSDERM-S in time is more rapid in comparison with LYSSTAPH-S. The detailed results are shown in Supplementary Material Figures S2 and S3.

\subsection{Growth Kinetic Analysis and Cluster Analysis}

The cultivation of $S$. aureus strains without LYSSTAPH-S or LYSDERM-S presence did not show any significant difference in the growth rate among the tested strains, and all of the strains reached stationary phase after $4 \mathrm{~h}$ of cultivation.

The cultivation of $S$. aureus strains with increasing LYSSTAPH-S concentrations showed a distinct pattern present in all strains. Bacterial growth was affected by LYSSTAPH-S concentrations ranging from 0.625 to $2.5 \mu \mathrm{g} / \mathrm{mL}$ only when the stationary phase was reached. This is probably due to the rapid growth at the beginning of the experiment when nutrition was abundantly present in the growth medium. When the stationary phase was reached and cellular growth and division were limited, the lytic effect of the LYSSTAPH-S outweighed the peptidoglycan construction and the repair mechanisms and bacterial cells were disrupted, thus the optical density of the medium decreased. This effect is depicted in Figures 3 and 4 for ST22 and ST30, respectively. Higher concentrations partially or entirely inhibited bacterial growth. The full results of the other tested $S$. aureus strains are shown in Supplementary Material Figure S4.

\section{Effect of LYSSTAPH-S concentration on S. aureus strain ST22}

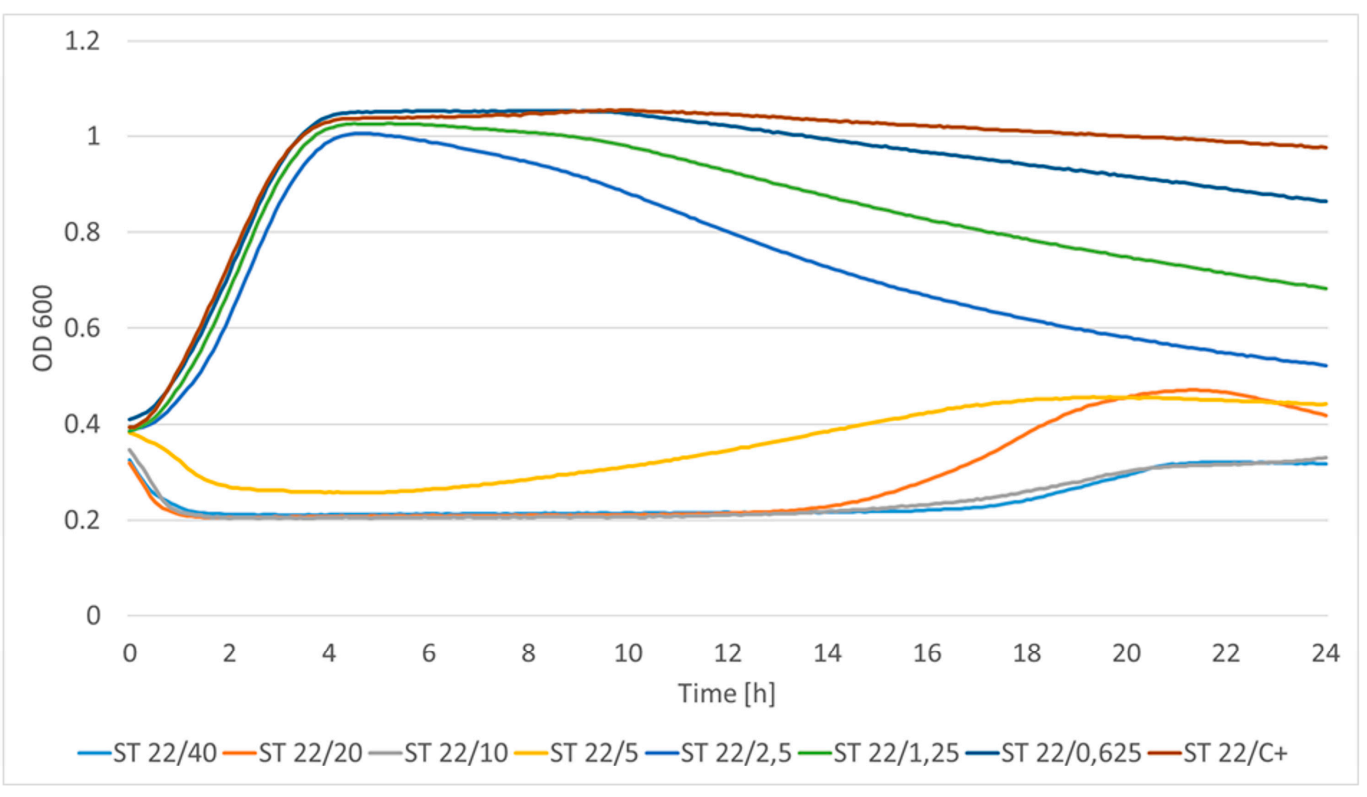

Figure 3. The concentration effect of the added LYSSTAPH-S on S. aureus ST22 strain. Concentrations ranging from 0.625 to $2.5 \mu \mathrm{g} / \mathrm{mL}$ affect the growth curve only when the stationary phase is reached. The decrease in optical density is concentration-dependent (particular concentration in $\mu \mathrm{g} / \mathrm{mL}$ is mentioned after the slash sign). ST (sequence type of S. aureus), $\mathrm{C}+$ (growth control). 


\section{Effect of LYSSTAPH-S concentration on S. aureus strain ST 30}

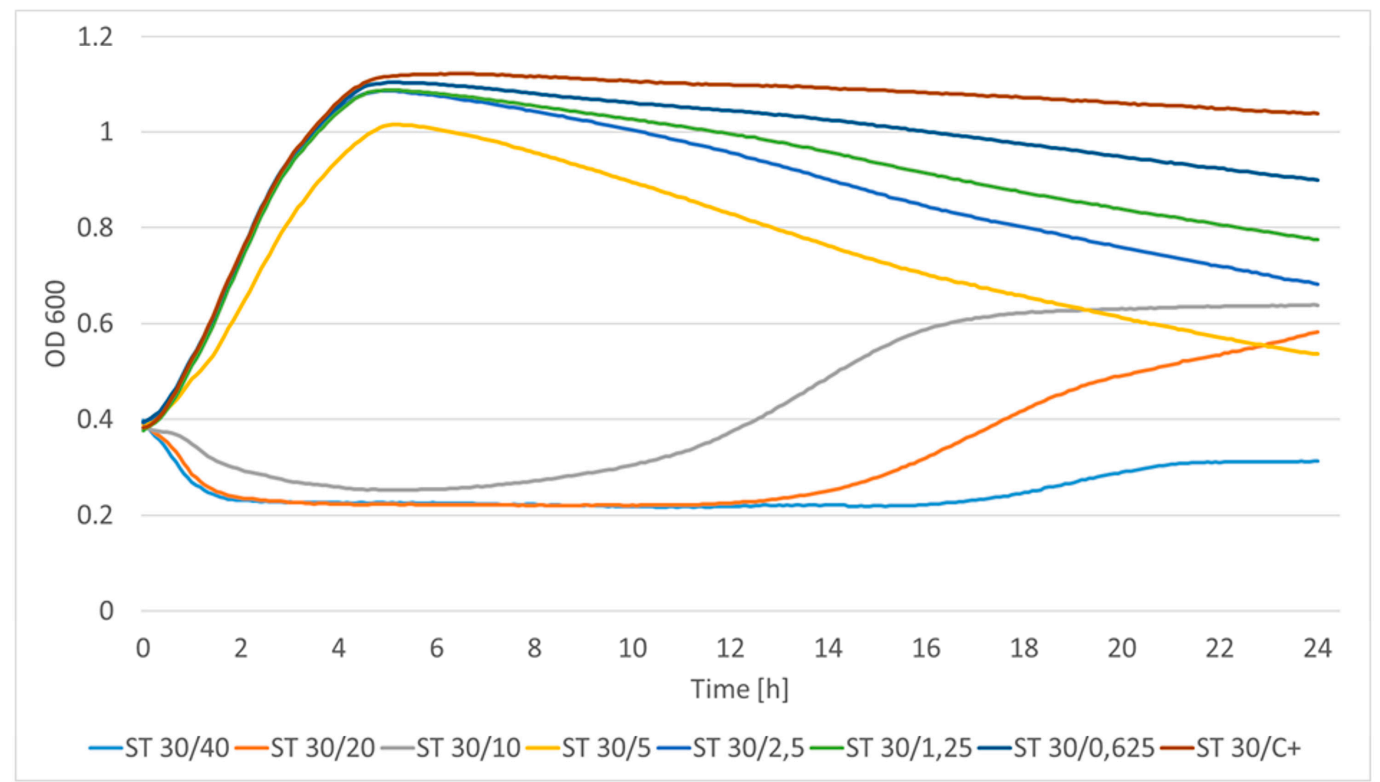

Figure 4. The concentration effect of added LYSSTAPH-S on S. aureus ST30 strain. Concentrations ranging from 0.625 to $5 \mu \mathrm{g} / \mathrm{mL}$ affect the growth curve only when the stationary phase is reached. The decrease in optical density is concentration-dependent (particular concentration in $\mu \mathrm{g} / \mathrm{mL}$ is mentioned after the slash sign). ST (sequence type of S. aureus), C+ (growth control).

The background optical density (OD) for the sterile cultivation medium was $0.207 \pm 0.021$ in our experiments. After the initial decrease of OD, which could be seen in earlier time points when high concentrations of the enzyme were used, OD levels dropped to the OD level of the background (sterile cultivation medium). Therefore, the formation of the degradation products and the possible interference with the OD measurement remained below the detection limit of this method. This implies that the degradation products had minimal to no effect on the OD measurement during this experiment.

Elevated levels of the OD at later time points suggested partially decreased activity of LYSSTAPH-S, which allowed for bacterial growth because nutrients in the cultivation medium had not been depleted yet. When nutrients were eventually depleted, and bacteria could not promptly grow and repair damages to their cell wall, the OD values started to decrease again, since LYSSTAPH-S still maintained part of its original activity. This effect can be seen in Figure 3, the growth curve of ST22 in the presence of $20 \mu \mathrm{g} / \mathrm{mL}$ of LYSSTAPH-S (orange line).

The cultivation of $S$. aureus strains with increasing LYSDERM-S concentrations showed a concentration-dependent lytic effect. The bacterial growth was affected by LYSDERM-S concentrations ranging from 7.8125 to $500 \mu \mathrm{g} / \mathrm{mL}$ only at the beginning of the experiment. The inoculum effect could be seen in the later phase of the experiment (antimicrobial effect dependent on the number of bacteria initially inoculated into the assay, in this assay $2 \times 10^{8} \mathrm{CFU} / \mathrm{mL}$ ). Strains ST22 and ST30 are shown in Figures 5 and 6, respectively. The full results of the other tested S. aureus strains are shown in Supplementary Material Figure S5. Strain ST30 (Figure 6) was not inhibited, even with the highest concentrations of LYSDERM-S tested $(500 \mu \mathrm{g} / \mathrm{mL})$. Other strains showed growth inhibition in the range of 15.625 to $62.5 \mu \mathrm{g} / \mathrm{mL}$ of LYSDERM-S concentration. 


\section{Effect of LYSDERM-S concentration on S. aureus strain ST 22}

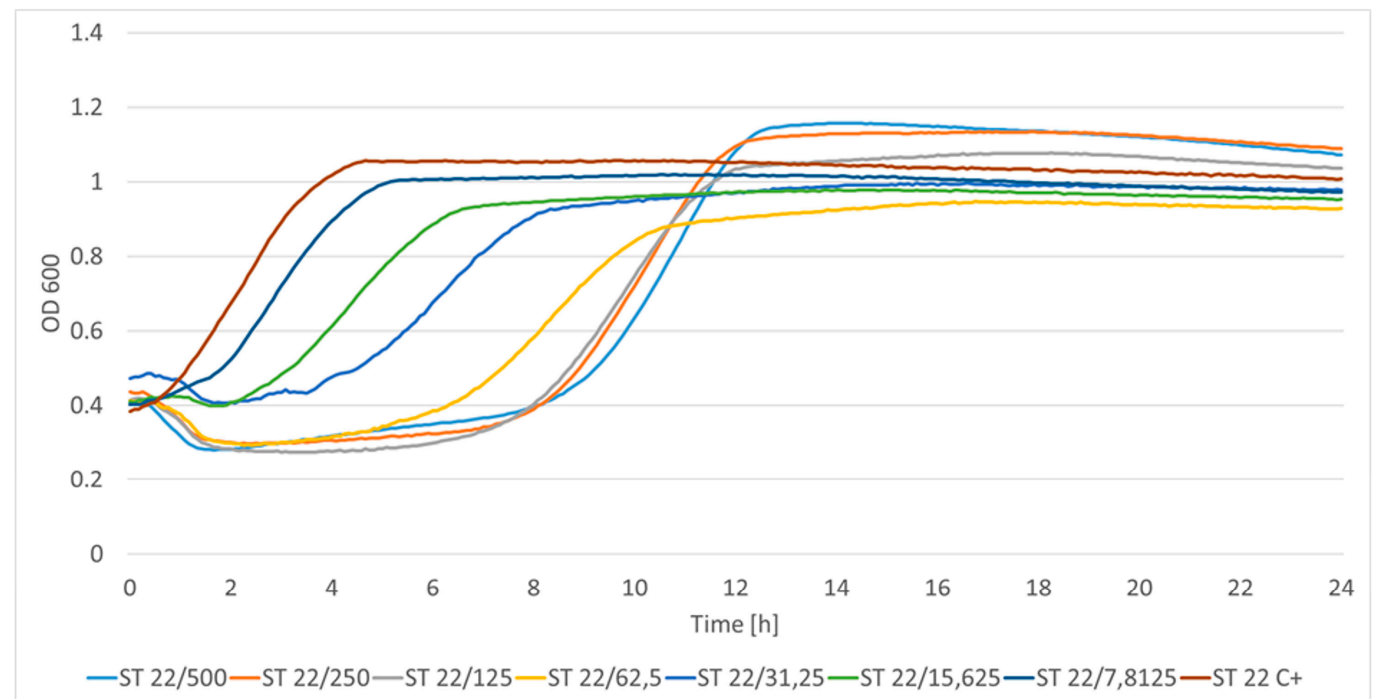

Figure 5. The concentration effect of added LYSDERM-S on S. aureus ST22 strain. Concentrations range from 7.8125 to $500 \mu \mathrm{g} / \mathrm{mL}$; the decrease in optical density is concentration-dependent (particular concentration in $\mu \mathrm{g} / \mathrm{mL}$ is mentioned after the slash sign). ST (sequence type of S. aureus), $\mathrm{C}+$ (growth control).

\section{Effect of LYSDERM-S concentration on S. aureus strain ST 30}

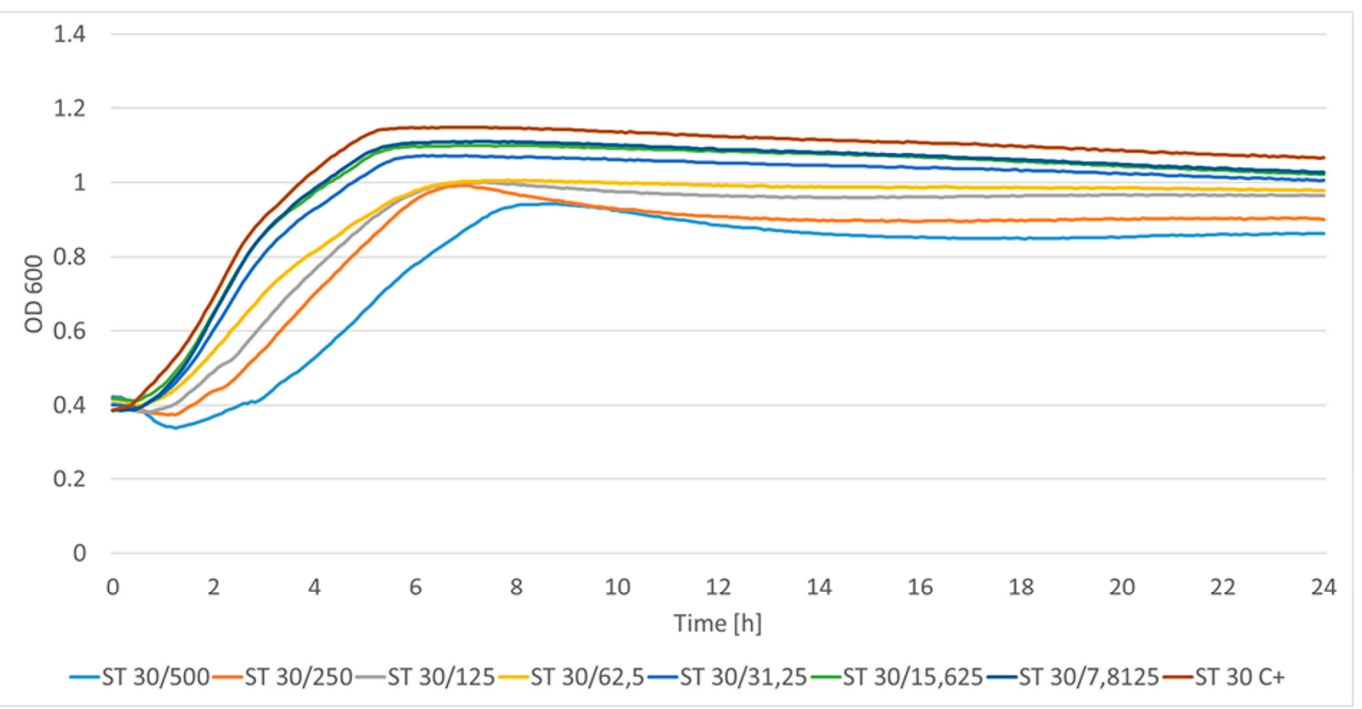

Figure 6. The concentration effect of added LYSDERM-S on S. aureus ST30 strain. Concentrations range from 7.8125 to $500 \mu \mathrm{g} / \mathrm{mL}$; the decrease in optical density is concentration-dependent (particular concentration in $\mu \mathrm{g} / \mathrm{mL}$ is mentioned after the slash sign). ST (sequence type of S. aureus), $\mathrm{C}+$ (growth control).

Based on growth characteristics over $24 \mathrm{~h}$, bacterial strains were subjected to cluster analysis and divided into five distinct groups, according to increasing resistance towards LYSSTAPH-S. S. aureus strains ST22, ST154, and ST225 were assigned to group 1 (increased susceptibility towards LYSSTAPH-S), 
ST8 and ST398 to group 2, ST7, ST15, ST45, ST80, and ST121 to group 3, two ST395 strains to group 4, and finally ST30 to group 5 (increased resistance towards LYSSTAPH-S).

\subsection{Bacterial Cluster Formation}

S. aureus strains ST22, ST30, and ST395 belonging to different groups due to their growth inhibition by LYSSTAPH-S were inspected for bacterial cluster formation by two different methods, by microscopic examination and by spectrophotometric quantification of the Helm's flocculation test. No significant difference $(p=0.198)$ among the tested strains was discovered (data not shown).

\subsection{Biofilm Formation Assay}

Quantification of produced biofilm in all strains examined by growth curve analysis was performed by the crystal violet biofilm assay. All tested strains showed medium to high biofilm formation. It is worth noting that strains determined as the most resistant toward LYSSTAPH-S and LYSDERM-S showed less tendency to form biofilms than the most susceptible strains (Figure 7).

\section{Biofilm quantity produced by different strains of S. aureus}

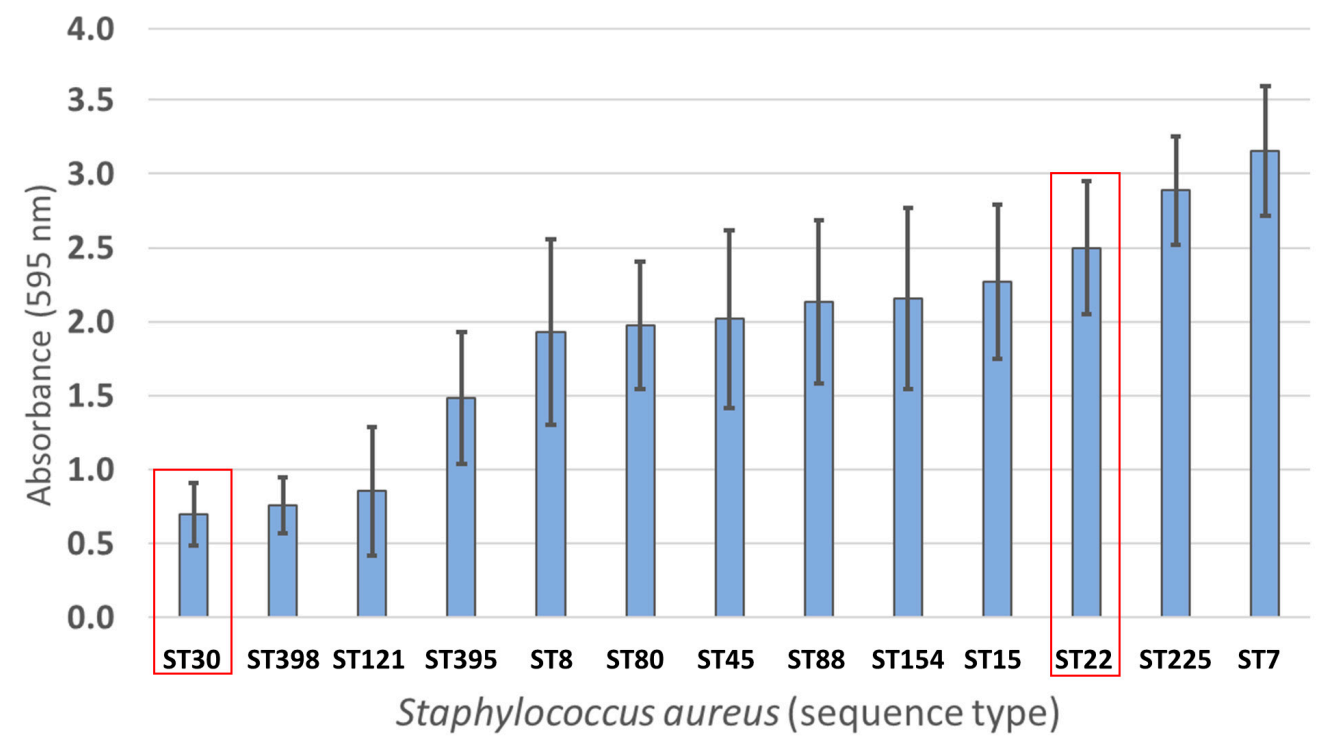

Figure 7. Quantification of produced biofilm of strains examined by growth curve analysis.

\subsection{Resistance to Vancomycin}

Reduced susceptibility to LYSSTAPH-S or LYSDERM-S due to increased vancomycin resistance was examined by minimal inhibitory concentration (MIC) determination. None of the tested strains were identified as vancomycin intermediate-resistant or vancomycin-resistant $S$. aureus.

\subsection{Peptidoglycan Analysis}

Four samples of peptidoglycan of S. aureus strains ST15, ST22, ST30, and ST154, and one sample of Staphylococcus epidermidis CCM 4418 (=ATCC 12228) peptidoglycan were analyzed after the treatment with the lytic enzymes LYSSTAPH-S and LYSDERM-S. High-performance liquid chromatography-mass spectrometry (HPLC-MS) analyses of digested peptidoglycans did not find significant differences among S. aureus samples based on (muro) peptide composition. The reference S. epidermidis strain showed a significant difference (additional peaks " $+30 \mathrm{Da}$ ") from S. aureus peptidoglycan due to the increased 
number of serine residues in the interpeptide bridge composition of its peptidoglycan. Figure 8 represents the differences in the peptidoglycan composition as determined by HPLC-MS analysis.

HPLC-MS analysis of the S. aureus and S. epidermidis peptidoglycan
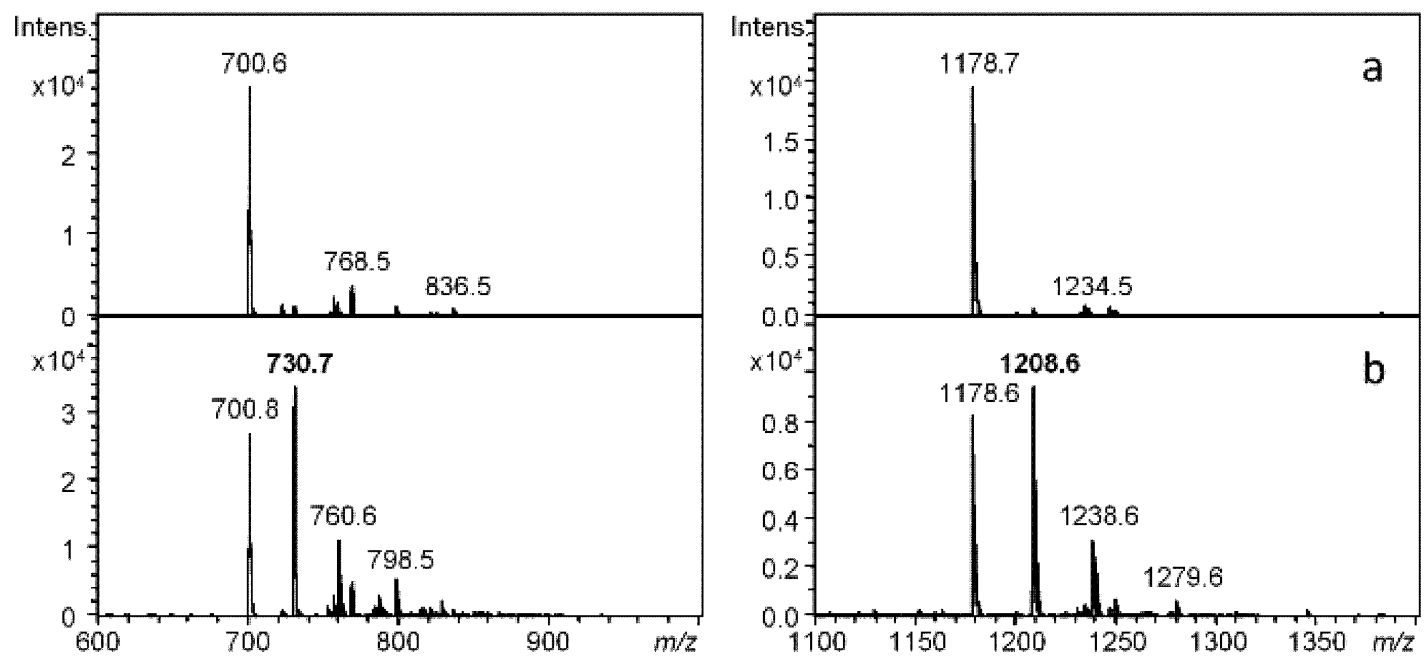

Figure 8. Mass spectrometry (MS) spectra of the peaks corresponding to selected peptides (left) and muropetides (right) derived from Staphylococcus aureus ST154 (a) and Staphylococcus epidermidis CCM 4418 (b) peptidoglycan after the action of LYSDERM-S. S epidermidis-specific ions are labeled with bold numbers corresponding to differences in the interpeptide bridge (30 Da represents substitution of glycine with serine residue).

\section{Discussion}

Novel antimicrobial agents are urgently needed for the reduction of antimicrobial resistance impacts. In this study, we present recombinant antimicrobial enzymes LYSSTAPH-S and LYSDERM-S and demonstrate their antimicrobial efficiency against the set of MRSA strains and their storage stability at $4{ }^{\circ} \mathrm{C}$ for enzyme solution. We optimized the production of LYSSTAPH-S and LYSDERM-S expressed in E. coli in the pUbEx15 vector to minimize the production time and costs. The protein production was comparable to other expression systems and achieved yields of $200 \mathrm{mg} / \mathrm{L}$. Our production in a small-scale laboratory expression system exceeded conventional laboratory expression systems $(20 \mathrm{mg} / \mathrm{L})$ and reached concentrations commonly achieved at the semi-ind ustrial level (300 mg/L) [27-29]. Our final goal was to achieve a yield close to the $5 \mathrm{~g} / \mathrm{L}$ medium. We are currently testing an expression system capable of producing both recombinant proteins in a bioreactor with the future prospect of using these recombinantly prepared enzymes for topical application in chronic wound treatment.

Chronic infections are generally less understood, but studies suggest that stationary-phase liquid bacterial cultures and chronic-wound fitness of bacteria correlate significantly. Morgan et al. [30] demonstrated this situation in the most predominant bacterial species found in chronic wounds, Pseudomonas aeruginosa. Therefore, we based our observations not only on the commonly used turbidity reduction assay, which monitors turbidity levels during the period of one to several hours [31] but prolonged this time up to $24 \mathrm{~h}$. To our knowledge, there is no study that would closely monitor growth kinetics of MRSA strains in the presence of lysostaphin or endolysin LysK or their derivatives over a prolonged period of time in the high-throughput set-up of 384-well microplates.

The growth kinetic analysis implies that LYSSTAPH-S is not affected by $S$. aureus defense mechanisms and antimicrobial activity is stably maintained over a 24-h long measurement. The growth kinetic analysis revealed that even concentrations lower than $1 \mu \mathrm{g} / \mathrm{mL}$ of LYSSTAPH-S significantly affect staphylococci in the stationary phase. This is particularly important for future applications in chronic infections management. Moreover, concentrations over $10 \mu \mathrm{g} / \mathrm{mL}$ are capable of lysing 
staphylococcal cells in the exponential phase of growth. These results indicate that higher concentrations of enzyme should be used to treat acute infections.

Further, Wu et al. [32] recently pointed out the difference between the susceptibility of lysostaphin in the non-growth environment of phosphate-buffered saline (PBS) and the growth-supporting medium tryptic soy broth (TSB). They confirmed the low cleavage of pentaglycine bridges and low bacterial cell killing in TSB caused by lysostaphin. Our findings are in agreement with this result and we would like to note that bacteria in chronic wound infections are found in the state of high-density bacterial growth conditions and are supplemented by the limited supply of nutrients provided by wound exudate, and, therefore, reside in conditions closely resembling the stationary phase in the growth-supporting medium [30]. Considering this, LYSSTAPH-S seems to be a suitable candidate for further testing and, possibly, clinical trials in the field of chronic wound management.

The growth kinetic analysis of LYSDERM-S suggests an initial antibacterial effect, as seen in LYSSTAPH-S, but this response is concentration-dependent, diminishes over time, and the number of bacteria rises again. The LYSDERM-S probably loses its activity within several hours of testing. Also, LYSDERM-S seems to be less effective towards some sequence types of S. aureus, namely ST30. Even the highest concentrations of LYSDERM-S could not reduce the initial numbers of this bacterial strain.

The short-term antibacterial effect of LYSDERM-S could be explained by the inoculum effect (the inoculum density was higher than for a standard antibiotic susceptibility testing) and the enzyme stability. The initial high bacterial concentration might influence the later stages of kinetic analysis where bacterial counts rise again. This effect is well known in standard antimicrobial susceptibility testing [33]. Further, our previous assessment of the stability of the tested proteins by the melting curve analysis showed a difference of $20^{\circ} \mathrm{C}$ in $\mathrm{T}_{\mathrm{m}}$ between these two enzymes (data not shown). This would indicate that LYSDERM-S has a greater tendency to denature during growth kinetic analysis compared to LYSSTAPH-S. These hypotheses are also supported by the plate lysis assay repeated over a period of 12 weeks. For example, the previous studies showed that the addition of $\mathrm{Ca}^{2+}$ cations resulted in an enhanced (more than 100 times) stability of LysK endolysin [34], and we argue that further structural stabilization of LYSDERM-S by recombination might increase its antibacterial effectivity. We see the improvement of structural instability as an important goal for future research.

Considering other aspects, we found that the level of bacterial susceptibility was independent of other growth parameters tested, such as cluster formation or biofilm development. Also, the target site, pentaglycine bridge within the peptidoglycan, of these enzymes also seemed to be similar among the tested strains and did not show any variability across the tested strains. Therefore, it remains unclear where the basis of the different susceptibility lies.

Nevertheless, LYSSTAPH-S and LYSDERM-S antimicrobial enzymes proved to be efficient in killing of the diverse strains of methicillin-resistant S. aureus. As a result, we believe that even well studied antimicrobial enzymes, such as lysostaphin and endolysin LysK and their derivatives could be further modified in order to improve their antimicrobial properties and stability and ultimately serve as a worthy alternative to well-established antimicrobial therapy of methicillin-resistant $S$. aureus infections.

\section{Materials and Methods}

\subsection{Bacterial Strain Selection}

Staphylococcus aureus strains were selected from the Collection of Microorganisms of the Department of Experimental Biology, Faculty of Science, Masaryk University, Czech Republic. Based on multilocus sequence typing (MLST) of human and veterinary S. aureus strains in this collection, candidate sequence type (ST) strains were selected to obtain the most heterogeneous representatives of each clonal cluster (CC). The selected representatives of S. aureus strains belonged to ST1, ST5, ST7, ST8, ST15, ST22, ST30, ST45, ST80, ST88, ST121, ST154, ST225, ST239, ST395, and ST398. 


\subsection{Enzyme Preparation}

The expression vector pUbEx15 was constructed from the vector pET28 by insertion of special DNA cassettes by $\mathrm{XbaI}$ and BamHI restriction enzymes. The DNA cassette contains the optimized gene for heterologous expression in E. coli for ubiquitin, 14-His-Tag, and the target site for Tobacco Etch Virus (TEV) protease. The full sequences of the LYSSTAPH-S and LYSDERM-S genes were synthesized by GenScript Biotech (Leiden, The Netherlands), optimized for heterologous expression in E. coli, and inserted into the vector pUbEx15 by NcoI and NotI restriction enzyme [35].

Both enzymes LYSSTAPH-S and LYSDERM-S were produced in the E. coli strain BL21 (DE3) carrying pUbEx15 plasmid and grown in 1 L flasks containing $200 \mathrm{~mL}$ LB medium supplemented with $50 \mu \mathrm{g} / \mathrm{mL}$ kanamycin at $37^{\circ} \mathrm{C}$ and $180 \mathrm{rpm}$. When the optical density (OD 600) reached 0.6, the recombinant protein expression was induced by the addition of IPTG to the final concentration of $0.4 \mathrm{mM}$, and the culture was further incubated for $16 \mathrm{~h}$ at $20{ }^{\circ} \mathrm{C}$. The cells were harvested by centrifugation at $6000 \times g$ and $4^{\circ} \mathrm{C}$ for $10 \mathrm{~min}$., then resuspended in lysis buffer $(100 \mathrm{mM}$ Tris- $\mathrm{HCl}, \mathrm{pH}=8$, with $400 \mathrm{mM} \mathrm{NaCl}, 0.1 \%$ Triton X-100 and lysozyme to the final concentration $10 \mu \mathrm{g} / \mathrm{mL}$ ), and sonicated for 15 min on ice (1 s pulses with 4 s intervals, amplitude 35\%; SonoPlus Badelin, (Berlin, Germany)). Both suspensions were centrifuged for $30 \mathrm{~min}$ at $15,000 \times g$ and $4{ }^{\circ} \mathrm{C}$, filtered through $0.22 \mu \mathrm{m}$ filter (Techno Plastic Products AG, Trasadingen, Switzerland), and the supernatants were used for protein purification. Both supernatants were loaded onto HisTrap equilibrated with $100 \mathrm{mM}$ Tris-HCl buffer, $\mathrm{pH}=8$, with $400 \mathrm{mM} \mathrm{NaCl}, 10 \mathrm{mM}$ imidazole. LYSSTAPH-S and LYSDERM-S were eluted with the same elution buffer (100 mM Tris- $\mathrm{HCl}, 400 \mathrm{mM} \mathrm{NaCl}$ and $300 \mathrm{mM}$ imidazole). After purification, the proteins were dialyzed against an ammonium acetate buffer $(0.1 \mathrm{M}, \mathrm{pH}=5.5$; Oxoid, UK). The protein concentrations were determined using the BCA microplate assay with bovine serum albumin (BSA) as a standard according to the manufacturer's instructions (measured with Pierce ${ }^{\mathrm{TM}}$ BCA Protein Assay Kit, Thermo Scientific, Waltham, MA, USA). The presence of the target protein was further verified with preparative electrophoresis in a polyacrylamide gel (Model 491 Prep Cell, BioRad, Hercules, CA, USA) according to the manufacturer's protocol. For protein expression and purity verification, the SDS-PAGE was used. The yield of both pure proteins calculated on $1 \mathrm{~L}$ of the growth medium was about $200 \mathrm{mg}$.

\subsection{Plate Lysis Assay}

Purified LYSSTAPH-S and LYSDERM-S solutions were serially diluted in distilled water to obtain final concentrations of 800, 400, 200, 100, 50, and $25 \mu \mathrm{g} / \mathrm{mL}$. Each staphylococcal strain was cultivated overnight in $20 \mathrm{~mL}$ of meat peptone broth (MPB) prepared from nutrient broth $13 \mathrm{~g} / \mathrm{L}$, yeast extract $3 \mathrm{~g} / \mathrm{L}$, bacteriological pepton $5 \mathrm{~g} / \mathrm{L}, \mathrm{pH}=7.4$ (Oxoid, $\mathrm{UK}$ ) at $37^{\circ} \mathrm{C}$ with shaking. Overnight cultures were then diluted 1:500 in a fresh MPB and further cultivated for $4 \mathrm{~h}$ to reach the mid-exponential phase. The cells were harvested by centrifugation at $6000 \times g$ and $4{ }^{\circ} \mathrm{C}$ for $10 \mathrm{~min}$. The cells were washed and resuspended in PBS buffer (Oxoid, UK) three times. Next, bacterial cultures were resuspended in PBS to obtain the final optical density of 0.5 McFarland standard and swabbed uniformly across Trypticase Soy Agar with 5\% Sheep Blood culture plates (bioMérieux, Craponne, France). $10 \mu \mathrm{L}$ of each purified LYSSTAPH-S dilution was spotted onto a freshly plated lawn of $S$. aureus. The spotted plates were incubated overnight at $37^{\circ} \mathrm{C}$. After $20-24 \mathrm{~h}$ of cultivation, inhibition zones were observed and semiquantitatively evaluated. LYSSTAPH-S and LYSDERM-S solutions were then stored at $4{ }^{\circ} \mathrm{C}$ for 6 and 12 weeks as enzyme solutions and experiments were repeated to re-evaluate stability and antibacterial effect.

\subsection{Growth Kinetic Analysis and Cluster Analysis}

Purified LYSSTAPH-S was serially diluted in PBS to obtain stock concentrations of 400, 200, 100, 50, $25,12.5$, and $6.25 \mu \mathrm{g} / \mathrm{mL}$. Purified LYSDERM-S was serially diluted in PBS to obtain stock concentrations of 5000, 2500, 1250, 625, 312.5, 156, 25, and 78.125 $\mu \mathrm{g} / \mathrm{mL}$. Each staphylococcal strain was cultivated 
overnight in $20 \mathrm{~mL}$ of Trypticase Soy Broth (TSB, Oxoid, UK) at $37^{\circ} \mathrm{C}$ with shaking. Overnight cultures were then diluted 1:500 in a fresh TSB and further cultivated for $4 \mathrm{~h}$ to reach the mid-exponential phase. Bacterial cultures were then diluted with fresh TSB to obtain a bacterial suspension of the final optical density of $\left(\mathrm{OD}_{600}\right)=0.2$ (approx. $\left.2 \times 10^{8} \mathrm{CFU} / \mathrm{mL}\right) .90 \mu \mathrm{L}$ of each strain suspension and $10 \mu \mathrm{L}$ of each LYSSTAPH-S and LYSDERM-S stock solutions were mixed in Nunc ${ }^{\circledR}$ 384-well microplates (Sigma-Aldrich, St. Louis, MO, USA) in triplicates and sealed with sterile ThermalSeal ${ }^{\circledR}$ films (Sigma-Aldrich, St. Louis, MO, USA). $10 \mu \mathrm{L}$ PBS was added to each strain suspension to serve as growth control. Microplates were incubated at $37{ }^{\circ} \mathrm{C}$ with shaking in Tecan Infinite M200 PRO microplate reader (Tecan Trading AG, Trasadingen, Switzerland), and optical density was measured $(A=600 \mathrm{~nm})$ every $5 \mathrm{~min}$ for $24 \mathrm{~h}$. The cultivation was repeated three times to obtain nine growth curves for each bacterial strain and LYSSTAPH-S or LYSDEERM-S dilution.

Average growth curves were obtained for each bacterial strain and lysostaphin dilution and compared among themselves. Dendrogram of average growth curves was obtained to help to assess the ideal number of clusters for cluster analysis (TIBCO Statistica 13.5, TIBCO Software Inc., New York, NY, USA). Next, bacterial strains were divided into five groups based on the obtained dendrogram and empirical evaluation (cluster analysis algorithm: k-Means, number of iterations: 50, distance method: Euclidean distances; TIBCO Statistica 13.5, TIBCO Software Inc., USA), and representative members of groups with the most dissimilar growth curve timelines were selected for further analyses.

\subsection{Bacterial Cluster Formation}

Bacterial cluster formation was inspected in S. aureus strains ST22, ST30, and ST395 by two different methods. The first method relied on the microscopical evaluation of clusters. In brief, $20 \mu \mathrm{L}$ of each overnight bacterial suspension (cultivation in TSB at $37^{\circ} \mathrm{C}$ ) was directly stained by adding $5 \mu \mathrm{L}$ of Alcian Blue 8 GX (Sigma-Aldrich, St. Louis, MO, USA) to avoid possible cluster disruption. Specimens were visually examined by a 40× phase-contrast objective (magnification 400×, Nikon ECLIPSE Ci-E, Nikon Corp., Tokyo, Japan) to assess the number and size of clusters.

In the second method, the methodology used for the spectrophotometric quantification of Helm's flocculation test [36] was adopted. In brief, bacterial suspensions were obtained as described in the Plate Lysis Assay, with the bacterial cultivation in TSB instead of MPB. Optical density (OD 600) of $2 \mathrm{~mL}$ of each bacterial suspension was measured immediately in disposable cuvettes. Further, bacterial suspensions in the disposable cuvettes were let to settle freely for $3 \mathrm{~h}$ at ambient temperature. After the given time, $500 \mu \mathrm{L}$ of the upper portion of the suspensions were taken, optical density at $600 \mathrm{~nm}$ was measured again and compared to the OD value before the settling period. The experiment was repeated three times in triplicates. The differences in OD values for bacterial strains were compared by one-way ANOVA (TIBCO Statistica 13.5, TIBCO Software Inc., New York, NY, USA).

\subsection{Biofilm Formation Assay}

The biofilm formation assay followed the standard methodology described in Stepanović et al. [37]. In brief, bacterial strains were grown overnight in TSB and then diluted 1:500 in a fresh TSB and further cultivated for $4 \mathrm{~h}$ to reach the mid-exponential phase. Bacterial cultures were then diluted with fresh TSB to obtain bacterial suspensions of optical density $0.5 \mathrm{McF}$ arland standard (approx. $1-2 \times 10^{8} \mathrm{CFU} / \mathrm{mL}$ ). Then bacterial suspensions were further diluted 1:100 with TSB medium supplemented with $1 \%$ glucose. A total of $200 \mu \mathrm{L}$ of each bacterial suspension was pipetted into microtiter plates in triplicates and incubated for $20 \mathrm{~h}$ at $37^{\circ} \mathrm{C}$. After the incubation, the bacterial suspension was carefully removed, and the biofilm was gently washed three times with PBS. The biofilm was fixed by heat at $37^{\circ} \mathrm{C}$ overnight and subsequently stained with a $1 \%$ crystal violet solution (Sigma-Aldrich, St. Louis, MO, USA) for $20 \mathrm{~min}$. The excess of the staining solution was removed by rinsing in running water. Bound crystal violet was resuspended in $200 \mu \mathrm{L}$ of $33 \%$ acetic acid (Sigma-Aldrich, St. Louis, MO, USA), and the absorbance at $595 \mathrm{~nm}$ was determined using a Tecan Infinite M200 PRO microplate reader (Tecan Trading AG, Trasadingen, Switzerland). 


\subsection{Resistance to Vancomycin}

As described earlier, vancomycin-resistant strains exhibit reduced susceptibility to lysostaphin. To examine this effect, minimal inhibitory concentrations (MIC) were determined for each S. aureus strain following the broth microdilution methodology according to European Committee on Antimicrobial Susceptibility Testing (EUCAST) recommendations. In brief, bacterial cell suspensions of all selected strains were prepared $\left(5 \times 10^{5} \mathrm{CFU} / \mathrm{mL}\right)$ in Mueller-Hinton broth (Oxoid, UK) and commercial MIC sets containing vancomycin in concentrations ranging from 0.5 to $32 \mathrm{mg} / \mathrm{L}$ in two-fold dilutions were inoculated. MIC sets were cultivated for $20 \mathrm{~h}$ at $37^{\circ} \mathrm{C}$ and subsequently visually inspected for turbid growth. MIC values were determined as the first well with no visible turbid growth. VISA strains were characterized by MIC in the range of 4 to $8 \mathrm{mg} / \mathrm{L}$, vancomycin-resistant $S$. aureus (VRSA) strains were characterized by $\mathrm{MIC}>8 \mathrm{mg} / \mathrm{L}$.

\subsection{Preparation of Bacterial Peptidoglycan}

Staphylococcus aureus strains ST15, ST22, ST30, and ST154 were used for peptidoglycan analysis and Staphylococcus epidermidis CCM 4418 (=ATCC 12228) served as a reference control strain. Staphylococcal strains were cultivated in $200 \mathrm{~mL}$ of meat peptone broth (MPB) prepared from nutrient broth $13 \mathrm{~g} / \mathrm{L}$, yeast extract $3 \mathrm{~g} / \mathrm{L}$, bacteriological peptone $5 \mathrm{~g} / \mathrm{L}, \mathrm{pH}=7.4$ (Oxoid, UK) at $37{ }^{\circ} \mathrm{C}$ with shaking to a final $\mathrm{OD}_{600}=1.5$. Bacteria were centrifuged at $5000 \times g$ and resuspended in $1 / 5$ of original volume $8 \%$ SDS and boiled for $30 \mathrm{~min}$ with the addition of water to maintain a constant volume. After cooling to room temperature, insoluble cell wall fragments were recovered by centrifugation at $3000 \times g$ for $15 \mathrm{~min}$. The SDS treatment was repeated four times on the insoluble material to remove proteins and nucleic acids.

Lyophilized LYSSTAPH-S was dissolved in water to obtain a concentration of $1 \mathrm{mg} / \mathrm{mL}$. A total of $500 \mu \mathrm{L}$ of LYSSTAPH-S solution was mixed with $2.5-3.5 \mathrm{mg}$ lyophilized peptidoglycan. Enzymatic cleavage occurred for $18 \mathrm{~h}$ at $37^{\circ} \mathrm{C}$ with agitation $(600 \mathrm{rpm})$. The suspension was separated by centrifugation and the supernatant was analyzed by LC-MS technique without further treatment.

\subsection{Peptidoglycan HPLC-MS Analysis}

HPLC-MS experiments were focused on the separation and identification of individual products of enzymatic digestion of the peptidoglycan. Chromatographic analyses were carried out on an Agilent 1100 series instrument (Agilent Technologies, Santa Clara CA, USA) coupled with a diode-array detector (Agilent Technologies, Santa Clara CA, USA) and an ion-trap mass spectrometer amaZon SL equipped with an ESI ion source (Bruker Daltonics, Fremont, CA, USA). The chromatographic separation was performed on Poroshell 120 SB-AQ column $(150 \times 2.1 \mathrm{~mm} ; 2.7 \mu \mathrm{m})$ (Agilent Technologies, Santa Clara CA, USA) at $35^{\circ} \mathrm{C}$. The mobile phase consisted of eluent A: $0.1 \%$ formic acid in water and eluent B: $0.1 \%$ formic acid in methanol at a flow rate of $0.2 \mathrm{~mL} \mathrm{~min}^{-1}$. The gradient started at $1 \%$ of $\mathrm{B}$, increased at a constant rate until $70 \%$ of B in $20 \mathrm{~min}$, then held constant until $25 \mathrm{~min}$, and then back to the initial $1 \%$, and held constant until $40 \mathrm{~min}$. The injected volume was $2.5 \mu \mathrm{L}$. The MS conditions were as follows: spray voltage, $-5.0 \mathrm{kV}$; the pressure of nebulizer gas, 25 psi; the flow of dry gas, $10 \mathrm{~L} / \mathrm{min}$; the temperature of dry gas, $300{ }^{\circ} \mathrm{C}$. The measurements were performed in Ultrascan mode in the range of m/z 70-2200. Structural analyses were based on MS data obtained in negative ion mode.

\section{Conclusions}

LYSSTAPH-S and LYSDERM-S were modified in order to improve their antimicrobial properties and stability and these antimicrobial enzymes proved to be efficient in killing of the diverse strains of methicillin-resistant Staphylococcus aureus. Further analyses proved no difference in the bacterial cell wall composition among the tested strains. Nevertheless, there was a significant difference in the biofilm formation among the strains. Unexpectedly, stronger biofilm producers were more susceptible to enzyme impact than the weak ones. 
Supplementary Materials: The following are available online at http://www.mdpi.com/2079-6382/9/8/519/s1, Figure S1: SDS-PAGE electrophoresis of recombinant proteins LYSDERM-S and LYSSTAPH-S. L (cell lysate), FT (flow-through), W (washed), P (pure protein), S (standard; ThermoFisher \#26623). Figure S2: Antibacterial susceptibility to LYSSTAPH-S of $S$. aureus strains (sequence types ST1, ST5, ST7, ST8, ST15, ST22, ST30, ST45, ST80, ST88, ST121, ST154, ST225, ST239, ST395, and ST398) as determined by the plate lysis assay. Concentrations used: $800,400,200,100,50,25 \mu \mathrm{g} / \mathrm{mL}$. Figure S3: Antibacterial susceptibility to LYSSTAPH-S of $S$. aureus strains (sequence types $1,5,8,22,30,45,225,239,398$ ) as determined by the plate lysis assay. Concentrations used: 800, 400, 200, 100, 50, $25 \mu \mathrm{g} / \mathrm{mL}$. Figure S4: Growth curves of S. aureus strains (sequence types ST7, ST8, ST15, ST45, ST80, ST88, ST121, ST154, ST225, ST395, and ST398) in the presence of LYSSTAPH-S as determined by the growth kinetic assay. Concentrations ranging from 0.625 to $40 \mu \mathrm{g} / \mathrm{mL}$. Figure S5: Growth curves of $S$. aureus strains (sequence types ST8, ST22, ST30, and ST225) in presence of or LYSDERM-S as determined by the growth kinetic assay. Concentrations ranging from 7.8125 to $500 \mu \mathrm{g} / \mathrm{mL}$

Author Contributions: Conceptualization L.V., Š.K., R.P., and L.J.; methodology L.V., Š.K., R.Č., R.P., and L.J.; investigation L.V., Š.K., R.Č.; validation L.V., Š.K., R.Č., R.P., and L.J.; resources L.V., Š.K., R.Č., R.P., and L.J. writing-original draft preparation, L.V., Š.K.; writing-review and editing L.V., Š.K., R.Č., R.P., and L.J.; visualization, L.V., Š.K., R.Č. and L.J.; supervision, R.P. and L.J.; project administration, L.J.; funding acquisition, L.J. All authors have read and agreed to the published version of the manuscript.

Funding: This research was funded by the Agency for Health Research of the Czech Republic (grant number NV19-05-00214).

Acknowledgments: We would like to express our very great appreciation to Filip Růžička, and to Martin Faldyna, for their valuable and constructive suggestions and support during the planning, development, and execution of this research.

Conflicts of Interest: The authors declare no conflict of interest.

Patents: Utility model No. 28939/2015 and utility model No. 33404/2019.

\section{References}

1. WHO: Antimicrobial Resistance. Available online: https://www.who.int/health-topics/antimicrobialresistance (accessed on 30 June 2020).

2. Rice, L.B. Federal Funding for the Study of Antimicrobial Resistance in Nosocomial Pathogens: No ESKAPE. J. Infect. Dis. 2008, 197, 1079-1081. [CrossRef] [PubMed]

3. Santajit, S.; Indrawattana, N. Mechanisms of Antimicrobial Resistance in ESKAPE Pathogens. Biomed. Res. Int. 2016, 2016, 1-8. [CrossRef] [PubMed]

4. Ma, Y.; Wang, C.; Li, Y.; Li, J.; Wan, Q.; Chen, J.; Tay, F.R.; Niu, L. Considerations and Caveats in Combating ESKAPE Pathogens against Nosocomial Infections. Adv. Sci. 2020, 7, 1901872. [CrossRef] [PubMed]

5. Zhen, X.; Lundborg, C.S.; Sun, X.; Hu, X.; Dong, H. Economic burden of antibiotic resistance in ESKAPE organisms: A systematic review. Antimicrob. Resist. Infect. Control. 2019, 8, 137. [CrossRef]

6. Holmes, A.H.; Moore, L.S.P.; Sundsfjord, A.; Steinbakk, M.; Regmi, S.; Karkey, A.; Guerin, P.J.; Piddock, L.J.V. Understanding the mechanisms and drivers of antimicrobial resistance. Lancet 2016, 387, 176-187. [CrossRef]

7. Szweda, P.; Schielmann, M.; Kotlowski, R.; Gorczyca, G.; Zalewska, M.; Milewski, S. Peptidoglycan hydrolases-potential weapons against Staphylococcus aureus. Appl. Microbiol. Biotechnol. 2012, 96, 1157-1174. [CrossRef]

8. Schindler, C.A.; Schuhardt, V.T. Lysostaphin: A new bacteriolytic agent for the staphylococcus. Proc. Natl. Acad. Sci. USA 1964, 51, 414-421. [CrossRef]

9. Sabala, I.; Jagielska, E.; Bardelang, P.T.; Czapinska, H.; Dahms, S.O.; Sharpe, J.A.; James, R.; Than, M.E.; Thomas, N.R.; Bochtler, M. Crystal structure of the antimicrobial peptidase lysostaphin from Staphylococcus simulans. FEBS J. 2014, 281, 4112-4122. [CrossRef]

10. Ehlert, K.; Schröder, W.; Labischinski, H. Specificities of FemA and FemB for different glycine residues: FemB cannot substitute for FemA in staphylococcal peptidoglycan pentaglycine side chain formation. J. Bacteriol. 1997, 179, 7573-7576. [CrossRef]

11. Kusuma, C.; Jadanova, A.; Chanturiya, T.; Kokai-Kun, J.F. Lysostaphin-Resistant Variants of Staphylococcus aureus Demonstrate Reduced Fitness In Vitro and In Vivo. Antimicrob. Agents Chemother. 2007, 51, 475-482. [CrossRef]

12. Kumar, J.K. Lysostaphin: An antistaphylococcal agent. Appl. Microbiol. Biotechnol. 2008, 80, 555-561. [CrossRef] [PubMed] 
13. Morikawa, K.; Maruyama, A.; Inose, Y.; Higashide, M.; Hayashi, H.; Ohta, T. Overexpression of Sigma Factor, $\varsigma \mathrm{B}$, Urges Staphylococcus aureus to Thicken the Cell Wall and to Resist $\beta$-Lactams. Biochem. Biophys. Res. Commun. 2001, 288, 385-389. [CrossRef] [PubMed]

14. Koehl, J.L.; Muthaiyan, A.; Jayaswal, R.K.; Ehlert, K.; Labischinski, H.; Wilkinson, B.J. Cell Wall Composition and Decreased Autolytic Activity and Lysostaphin Susceptibility of Glycopeptide-Intermediate Staphylococcus aureus. Antimicrob. Agents Chemother. 2004, 48, 3749-3757. [CrossRef] [PubMed]

15. Gründling, A.; Missiakas, D.M.; Schneewind, O. Staphylococcus aureus mutants with increased lysostaphin resistance. J. Bacteriol. 2006, 188, 6286-6297. [CrossRef] [PubMed]

16. Kiri, N.; Archer, G.; Climo, M.W. Combinations of Lysostaphin with $\beta$-Lactams Are Synergistic against Oxacillin-Resistant Staphylococcus epidermidis. Antimicrob. Agents Chemother. 2002, 46, 2017-2020. [CrossRef]

17. Strandén, A.M.; Ehlert, K.; Labischinski, H.; Berger-Bächi, B. Cell wall monoglycine cross-bridges and methicillin hypersusceptibility in a femAB null mutant of methicillin-resistant Staphylococcus aureus. J. Bacteriol. 1997, 179, 9-16. [CrossRef]

18. Rohrer, S.; Maki, H.; Berger-Bächi, B. What makes resistance to methicillin heterogeneous? J. Med. Microbiol. 2003, 52, 605-607. [CrossRef]

19. O'Flaherty, S.; Coffey, A.; Meaney, W.; Fitzgerald, G.F.; Ross, R.P. The Recombinant Phage Lysin LysK Has a Broad Spectrum of Lytic Activity against Clinically Relevant Staphylococci, Including Methicillin-Resistant Staphylococcus aureus. J. Bacteriol. 2005, 187, 7161-7164. [CrossRef]

20. Becker, S.C.; Dong, S.; Baker, J.R.; Foster-Frey, J.; Pritchard, D.G.; Donovan, D.M. LysK CHAP endopeptidase domain is required for lysis of live staphylococcal cells. FEMS Microbiol. Lett. 2009, 294, 52-60. [CrossRef]

21. Fenton, M.; Ross, R.P.; McAuliffe, O.; O’Mahony, J.; Coffey, A. Characterization of the staphylococcal bacteriophage lysin CHAPK. J. Appl. Microbiol. 2011, 111, 1025-1035. [CrossRef]

22. Nelson, D.C.; Schmelcher, M.; Rodriguez-Rubio, L.; Klumpp, J.; Pritchard, D.G.; Dong, S.; Donovan, D.M. Endolysins as Antimicrobials. In Advances in Virus Research; Academic Press: Cambridge, MA, USA, 2012; Volume 83, pp. 299-365.

23. Gondil, V.S.; Harjai, K.; Chhibber, S. Endolysins as emerging alternative therapeutic agents to counter drug-resistant infections. Int. J. Antimicrob. Agents 2020, 55, 105844. [CrossRef] [PubMed]

24. Becker, S.C.; Roach, D.R.; Chauhan, V.S.; Shen, Y.; Foster-Frey, J.; Powell, A.M.; Bauchan, G.; Lease, R.A.; Mohammadi, H.; Harty, W.J.; et al. Triple-acting Lytic Enzyme Treatment of Drug-Resistant and Intracellular Staphylococcus aureus. Sci. Rep. 2016, 6, 25063. [CrossRef] [PubMed]

25. Farhangnia, L.; Ghaznavi-Rad, E.; Mollaee, N.; Abtahi, H. Cloning, Expression, and Purification of Recombinant Lysostaphin From Staphylococcus simulans. Jundishapur J. Microbiol. 2014, 7, e10009. [CrossRef] [PubMed]

26. Benešík, M.; Nováček, J.; Janda, L.; Dopitová, R.; Pernisová, M.; Melková, K.; Tišáková, L.; Doškař, J.; Žídek, L.; Hejátko, J.; et al. Role of SH3b binding domain in a natural deletion mutant of Kayvirus endolysin LysF1 with a broad range of lytic activity. Virus Genes 2018, 54, 130-139. [CrossRef]

27. Chandra Ojha, S.; Imtong, C.; Meetum, K.; Sakdee, S.; Katzenmeier, G.; Angsuthanasombat, C. Purification and characterization of the antibacterial peptidase lysostaphin from Staphylococcus simulans: Adverse influence of $\mathrm{Zn}^{2+}$ on bacteriolytic activity. Protein Expr. Purif. 2018, 151, 106-112. [CrossRef]

28. Mierau, I.; Olieman, K.; Mond, J.; Smid, E.J. Optimization of the Lactococcus lactis nisin-controlled gene expression system NICE for industrial applications. Microb. Cell Fact. 2005, 4, 16. [CrossRef]

29. McCoy, M. KILLING STAPH TOGETHER: CASE STUDY \#2 Start-up Biosynexus places fermentation project in newly started Avecia facility. Chem. Eng. News 2004, 82, 36-40.

30. Morgan, S.J.; Lippman, S.I.; Bautista, G.E.; Harrison, J.J.; Harding, C.L.; Gallagher, L.A.; Cheng, A.-C.; Siehnel, R.; Ravishankar, S.; Usui, M.L.; et al. Bacterial fitness in chronic wounds appears to be mediated by the capacity for high-density growth, not virulence or biofilm functions. PLoS Pathog. 2019, 15, e1007511. [CrossRef]

31. Abtahi, H.; Farhangnia, L.; Ghaznavi-Rad, E. In Vitro and in Vivo Antistaphylococcal Activity Determination of the New Recombinant Lysostaphin Protein. Jundishapur J. Microbiol. 2016, 9, e28489. [CrossRef]

32. Wu, X.; Zha, J.; Koffas, M.A.G.; Dordick, J.S. Reducing Staphylococcus aureus resistance to lysostaphin using CRISPR-dCas9. Biotechnol. Bioeng. 2019, 116, 3149-3159. [CrossRef] 
33. Smith, K.P.; Kirby, J.E. The Inoculum Effect in the Era of Multidrug Resistance: Minor Differences in Inoculum Have Dramatic Effect on MIC Determination. Antimicrob. Agents Chemother. 2018, 62, e00433-18. [CrossRef] [PubMed]

34. Filatova, L.Y.; Becker, S.C.; Donovan, D.M.; Gladilin, A.K.; Klyachko, N.L. LysK, the enzyme lysing Staphylococcus aureus cells: Specific kinetic features and approaches towards stabilization. Biochimie 2010, 92, 507-513. [CrossRef]

35. Janda, L.; Kobzová, Š.; Norek, A. Plasmid pUbEx20 k produkci proteinů pro komerční využití v heterologním expresním systému E.coli. 2019. Available online: https://www.vri.cz/userfiles/file/Funkcni_vzorek/2019/ VUVeL-Funkcni_vzorek-5792-Janda-Plasmid_pUbEx20_k_prod_proteinu_pro_kom_vyuz_v_heterolog expres_syst_Ecoli.pdf (accessed on 30 June 2020).

36. Bendiak, D.S. Quantification of the Helm's Flocculation Test. J. Am. Soc. Brew. Chem. 1994, 52, $120-122$. [CrossRef]

37. Stepanović, S.; Vuković, D.; Hola, V.; Di Bonaventura, G.; Djukić, S.; Ćirković, I.; Ruzicka, F. Quantification of biofilm in microtiter plates: Overview of testing conditions and practical recommendations for assessment of biofilm production by staphylococci. APMIS 2007, 115, 891-899. [CrossRef] [PubMed]

(C) 2020 by the authors. Licensee MDPI, Basel, Switzerland. This article is an open access article distributed under the terms and conditions of the Creative Commons Attribution (CC BY) license (http://creativecommons.org/licenses/by/4.0/). 